Parents representatives in the new participatory school council in Belgium (Flanders)

\author{
Jef C. Verhoeven
}

Ilse Van Heddegem

University of Leuven

CEDAR 6th International Conference: Education and training: towards the 21st century University of Warwick (UK)

29-31 March 1996 


\section{Parents' representatives in the new participatory school council in Belgium}

\section{(Flanders)}

Verhoeven J.C. and Van Heddegem I.

In recent years in many countries, school-based management and lay participation have been developed or improved (Deem, 1994, p. 35). In Belgium, too, parents, together with teachers and the local community, have joined new participatory councils. According to Vincent (1996a, p. 43), one of the four major parental roles parents play in schools is the parent as participant, the other three being supporter/learner, consumer, and the independent parent. Pennock (Vincent, 1996a, p. 133) stresses four reasons for introducing participatory democracy in the educational system: "to make the organisation concerned seem responsive to its clients or electorate; to legitimize its actions; to aid the personal development of individuals 'reached' by the new participatory ethos; or to overcome the alienation of those groups supposedly served by the organisation." Nevertheless, the involvement of parents in school-based management is not without problems.

\section{Parents and parent empowerment}

\section{Problems}

Participation of parents in school policy is almost natural since the school and the family are complementary educational settings. However, there are obstructions that impede the involvement of parents in the school. 
In Belgium, Vanderhoeven (1991-1992, p. 62) has suggested that parents are generally insufficiently aware of their rights and obligations in the participatory bodies. Their concern about the school very often blends with their concern for the interests of their own children. They readily accept that only teachers have a professional understanding of the problems of children at school and ascribe to them a great deal of autonomy. Moreover, parents are not easily contacted and gathered together as are teachers and pupils because they can only be at school infrequently and for short periods of time. Parents often think they do not need such meetings because they can have direct contacts with teachers and school leaders outside the participation council.

Verhoeven \& Gheysen (1993, p. 163-170) conducted 12 case studies on parent participation in schools in Flanders. The results confirm suggestions offered by Vanderhoeven. Although some school heads found parent participation a positive thing, most were critical. For example, some stated that parents lack competence to function in a participation council, are not interested in school policy (many parents do not want to be candidates or even vote), only care about their own children, and, ultimately, do not need a participation council because they already have a parents' council. Unlike the heads, the teachers in state schools are more positive about parent participation, which is also the case in independent schools, although a minority of teachers shared the opinions of the heads. Some were afraid that parents would interfere in teaching methods. The parents themselves, especially in the state schools, felt that they were being criticized by the other participatory parties and were aware that they had to fight for their rights. In the independent schools, the parents felt that they were more respected. 
Similar problems have been reported in the U.K. and the U.S.A., e.g. parent governors are often informed about the school but this is a particularistic kind of knowledge grounded in their own children's experiences that does not always lend itself to informed debate about overall policies and principles (Deem, 1996, p. 63; Fine, 1997, p. 461). Some schools have problems recruiting parent governors because not all parents are enthusiastic about attending school events (ILEA, 1987, p. 140; Fine, 1997, p. 460). Another problem is that parent governors are not always representative for the parent body as a whole (Johnson \& Ransom, 1987, p. 70; Fine, 1997, p. 460). Some parents feel that they cannot take advantage of all the opportunities for participation because of their lack of education, that they have nothing of value to contribute (Sallis, 1988, p. 60), or that they have no power (Fine, 1997, p. 460). Moreover, for many parents, it is a real problem to find time to attend meetings (Vincent, 1996a, p. 111). Nevertheless, many find it very rewarding to be properly involved in a school, and most schools nowadays make parents feel welcome. The problem is that very few schools make them feel necessary (Sallis, 1988, p. 162). The relationships between parents and education professionals are shaped by the unequal power relations between the two groups (Vincent, 1996a, p. 157; Fine, 1997, p. 461; Deem, Brehony \& Heath, 1995, p. 98). Some parents feel politely patronised by the teachers or even set up against them (Fine, 1997, p. 461). They feel very much disempowered (Vincent, 1996b, p. 4).

Who are the parent governors? 
Research in the U.K. has determined who the parent governors are. The NFER survey and Golby \& Lane concluded that the parent representative is educated, white, and middleclass. Women are well represented, but there are interesting variations in the sex balance between primary and secondary schools and in terms of the position of the chairperson (Golby, 1992, p. 79; Deem, Brehony \& Heath, 1995, pp. 51-54). A survey of 200 board members revealed that semi-skilled and unskilled workers were underrepresented and that women and men were equally represented (Munn, 1992, p. 96-97). Another conclusion was that the members' professional involvement in education was more frequent than would be expected from the general community ( $37 \%$ had worked in education). Thody (1989, p. 145) argued that an unequal spread of representation could mean a failure for democracy, and also showed that classes with fairly high incomes and levels of education participate more than others because their social background leads them to offer such service. "These are people who have already gained from the education service, and they take the opportunity for further participation presumably to ensure that this favourable gain continues." Moreover, social class, ethnicity, sex and schooling are responsible for tensions between lay governors and education professionals (Deem \& Brehony, 1992, p. 76).

Functioning of the participatory structures

In the U.K., several studies have been conducted to evaluate the participation of parents in local school policy. The results show that parent participation does not always function well. Many parents feel uninformed of their role and still feel excluded and unconsulted 
by the LEAs (Wolfendale, 1989, p. 109). A minority feels marginalised by manipulative heads, outranked by LEA-nominated veterans, mystified by educational jargon, and intimidated by paperwork. However, there is another minority among parent governors that knows exactly what to do (Golby, 1992, p. 73). Golby \& Appleby studied 19 school governing bodies and found that one quarter of the parent governors felt dominated by other governors and that they could contribute little to the discussions. Deem \& Brehony conducted fieldwork in 15 school governing bodies and concluded that the meetings were dominated by headmasters and chairpersons (Golby, 1992, p. 82). On the basis of three case studies on parental involvement, Fine (1997, p. 460) concluded that power, control, and activism by parents could vary strongly from school to school. Deem \& Brehony (1992, pp. 80-81), argued that decision-making power means more than attending meetings and expressing opinions: governors have to understand how schools function and have to play a role in the school processes and activities.

Tomlinson asked parents to what extent they wanted to be involved in the decisionmaking process and found that organizational and extra-curricular issues were preferred to curricula issues. Parents want information rather than involvement in decision making about the curriculum (Vincent, 1996a, p. 110). Chapman (1990, p. 238) came to the same conclusion, but put it more generally: the desire to exercise control shifts with the nature of the issue under consideration.

\section{Legal Frame of parent participation in Flanders}


The current global education policy of the Flemish government in Belgium stresses democratic decision-making and devolution. Whereas until the 1980s decision-making in the state schools was the prerogative of the Minister of Education, this is now the right of an independent body (ARGO) and the local school councils (LSC). Subsidised private and municipal schools ${ }^{1}$ already enjoyed wide autonomy, and these schools were free to consult staff councils or the like. ${ }^{2}$ The Participation Act of the Subsidised Education (October 23, 1991) $)^{3}$ provided for participation of teachers and parents in particular matters. What are these new structures?

Since the ARGO Act (19 December 1988) ${ }^{4}$, the Minister of Education is no longer the organising authority for state education. In his place came the ARGO, the Central Council (Centrale Raad) of which is responsible for the operation of ARGO and the state schools. The government provides the money on the basis of a budget proposed by the Central Council. The Central Council determines the pedagogical mission of the State school network, defines the curriculum, and co-ordinates the development of the State network. It appoints and promotes staff $\mathrm{f}^{5}$ and undertakes the financial and equipment management, except for the salaries, which are paid directly by the government to the teachers (Verhoeven et al., 1992).

1 Private and municipal schools, like state schools, receive the major part of their financial resources from the goverment. Therefore, private and municipal schools are also called subsidized schools.

2 In Flanders, the state schools provide education for $14.5 \%$ of the primary and secondary school pupils, the independent schools for 69.5\%, and the municipal schools for 16\% (1995-1996). Each group of schools is called a school network.

3 'Decreet betreffende de medezeggenschap in het gesubsidieerd onderwijs van 23 oktober 1991', Belgisch Staatsblad, 14/11/1991: 25527-25530.

4 'Bijzonder Decreet betreffende de Autonome Raad voor het Gemeenschapsonderwijs van 19 december 1988', Belgisch Staatsblad, 29/12/1988: 17818-17827.

5 Rights, duties, required diplomas, etc. are determined by the Act of 27 March 1991 on the judicial position of state education staff members. 
In each school or group of schools (when the schools are located at the same site), there is a local school council or LSC, ${ }^{6}$ four members of which are elected by the parents. In addition, four members of local economic, social and cultural organisations are appointed by the parents representatives, and three representatives of the pedagogical council ("pedagogisch college" ${ }^{7}$ ) are co-opted by the two former groups. The head of the school is also a member. If more schools belong to the council, only one head has the right to vote and this head acts as the governor ('afgevaardigd bestuurder'). The governor prepares the LSC meetings and executes its decisions. The chairperson and the vice-chairperson are elected by the members of the council from among the non-staff members of the council. The LSC approves the school work plan, which is proposed by the pedagogical council, selects temporary staff, who must have the formal qualifications set by the State, and proposes temporary staff for appointment to the Central Council. The LSC is also responsible for the financial and equipment management of the school, except for the salaries of the regular staff.

The decision-making structure of the independent and municipal schools is very diverse. In these schools, the main body is the organising authority, which manages one or more schools. Although this body acts as the legal decision-maker, in most schools the everyday management of the schools is granted to the head, who can take advice from the various councils (e.g. a management council, a staff council) but who retains responsibility for final decisions regarding didactics, curriculum, finance, equipment, staff, ${ }^{8}$ etc. (Devos, Vandenberghe \& Verhoeven, 1989). Since 1975, schools with more than 100 staff have

\footnotetext{
6 In schools with less than 1,000 pupils this council has 12 members, and 15 members if there are more pupils.

7 This council is elected by the staff of the school. The head is a member but cannot vote. This council is no innovation as it was already established in the schools before the ARGO Act.
} 
been obliged to have a works council, and those with more than 50 a health-and-safety council. Half of the representatives of these councils represent the school management and half the teachers' union. These councils have the right to give advice and to exercise general supervision. Decisions are taken only by the works council and only concerning the social administration in the school; it has no competence in other areas.

Since the Participation Act (23 October 1991), independent and municipal schools have been obliged to organise a participation council ('participatieraad'), chaired by the head, who has to be independent of the groups of the council. The groups represented in the participation council are the organising authority, the staff, the parents, and the co-opted representatives of the local community. Each faction has at least two representatives. Art. $19 \S 1$ states that, if the school has union representatives or elected members of the works council, these persons are then the representatives of the staff. For some issues, the works council and the participation council have similar obligations. That this might create problems is not surprising. As is the case in the works council, the participation council has no decision-making power but does have the right to advise on the general organisation and operation of the school, the planning of the school, and general criteria for counselling and grading pupils. However, it has the right to deliberate (striving for a consensus) about the criteria ${ }^{9}$ for the best distribution of time periods and the overall number of periods per teacher, the school rules, transportation, and the health and the safety of the pupils. This council also has the right to be informed about everything that affects school life. As these regulations make clear, the participation council does not

\footnotetext{
8 Selection and appointment of staff have to be done according to the Act of 27 March 1991 with respect to the legal position of staff in subsidized education and psycho-medical centers.

9 It should be stressed that the deliberation is about the 'criteria', not about the actual application of the criteria.
} 
reduce the responsibility of the organising authority or of the head. It only creates a forum of deliberation for participants in school life.

This new participatory structure was an innovation for the position of the parents in the school. Until these laws came into force on 1 April 1991 (in state schools) and 31 May 1992 (in city and independent schools), parents could be invited to advise in school matters but schools were not obliged to do so. This created a new challenge for the parents. They were not accustomed to participating in school policy making on equal terms with the other groups of the school and were not formally prepared for the task they had to fulfill.

\section{Data and Methods}

As the government saw this new structure as an instrument to improve the democratic process of decision-making in school-based management, the OBPWO ${ }^{10}$ commissioned a study to determine the extent to which the aims were attained. A representative answer was expected, so the survey approach was chosen. The researchers had previously conducted twelve case studies on the subject (Verhoeven \& Gheysen, 1993) that provided important background material for the construction of the survey. In February 1995, questionnaires were sent to schools in order to determine how the councils were functioning and how this functioning was perceived by the members. By the end of May 1995, we had received 4,298 questionnaires: $66 \%$ of the questionnaires

10 This research was financed by OBPWO ( Fund for Educational Policy and Practice-oriented Scientific Research) and conducted under the direction of M. Jegers (Free University of Brussels) and J.C. Verhoeven (Catholic University of Leuven). 
sent to state schools, $65 \%$ of those sent to municipal schools, and $67 \%$ of those sent to independent schools. The purpose of the survey was to obtain a representative picture of the operation of the councils seen from the standpoint of the different groups in the councils. Thus, we sent questionnaires to one member of each group in a representative sample of the councils. In this paper only one group, i.e. the parents' representatives is discussed. In each network, a large proportion of the parents replied: in state schools we received 240 copies or $60 \%$ of the mailed questionnaires, in municipal schools 140 or $64 \%$, and in independent schools 352 or $68 \% .{ }^{11}$

The purpose of the present paper is to describe the opinions of the parents concerning the LSC and the participation council. Until the establishment of these councils parents were not accustomed to participating in school policy making. This was an important innovation. Moreover, the power granted to the parents as members of the council differs among the school networks: councils in independent and in municipal schools have less power than the councils of the state schools. For this reason, we expected to see different types of membership of the parents in the three networks, different descriptions of the functioning of the councils, and different appreciations of these councils by the parents, etc. We also expected that most of the parents would have a higher than average schooling level and would mainly belong to other occupational groups than the working class.

We will here deal with the following questions: 1) Who are the parents' representatives? 2) Why did they become representatives and what do they know about the regulations

11 There is an overrepresentation of state and city school parents because a simple proportional sample would have been too small for the analysis. In order to correct for this overrepresentation, all the scores were appropriately weighted. 
of the council? 3) What do parents expect from their participation in the council? 4) What do they think the consequences of the council for school policy are? 5) How satisfied are they with their council?

\section{Research results}

Who are the parents' representatives?

Most of the parents in the councils are male (61\%), which fits the traditional picture that men more than women feel that they have a calling for official duties. This traditional attitude is even more pronounced when we take into account the decision-making domain of the different councils. In state schools, the council has the right to govern schools in some domains, whereas in the independent and the municipal schools the council has only the right to advise. The figures of Table I suggest that men are more eager to be a member of the council when the council can really determine school policy than when this is not the case. This may explain why $69 \%$ of the parents' representatives are men in state schools, but only $61 \%$ to $56 \%$ in the other schools.

(here Table I)

Most of the parents (47\%) were 41-50 years old, 44\% being younger than 40 and $9 \%$ older than 50, which was to be expected since most of the parents' representatives had children in the school.

It could be expected that the function of representative would be taken by parents with more than average schooling. About 6 of 10 parents had higher education $(21 \%$ 
university and $39 \%$ other types of higher education), $38 \%$ secondary school, and $2 \%$ only elementary education. In private schools, about $2 / 3$ of the parents had graduated from a university or other forms of higher education, whereas in state schools this figure was only $51 \%$. Also in England the 'highly educated' were better represented in councils (Golby, 1992; Thody, 1989; Deem, Brehony \& Heath, 1995, p.53).

This phenomenon mirrors, of course, the socio-economic background of the parents on the councils: $66 \%$ were clerical workers, $12 \%$ entrepreneurs, and only $7 \%$ manual labourers. Another substantial group was formed by housewives (11\%), a larger group than the retired people (8\%) (only in state schools), and the unemployed (2\%). Research in the U.K. (Munn, 1992) and the U.S.A. (Fine, 1997) also revealed that semi-skilled and unskilled labourers were underrepresented. It would have been interesting to know to what extent this overrepresentation of well-educated parents was influenced by there having been no elections in about one quarter of the councils (alike in the three networks) for the parents' representatives. Our data cannot answer this question.

(here Table II)

Legally correct, but not expected, was the presence of $8 \%$ of parents without children in the school, a phenomenon that is even more pronounced in state schools $(25 \%)$. $75 \%$ of the parents had one or two children at the school where they were a representative, and $17 \%$ had even 3 or more children at school.

Why did parents become representatives and are they well prepared to do the job? 
Asked about the main reasons of their membership of the councils, most of the parents cited their commitment to the school. This was the same in all school networks. The ranking of the other motives on the basis of the number of reasons mentioned by the parents varies among the networks.

Ideology is an important motive in state schools, but much less so in independent (Catholic) schools and municipal schools. This might be explained by the politicization of the relations in the state schools, which finds some support in the large number of parents in state schools expressing their commitment to this network, which has had to be defended against the popularity of the major independent network. About one third of the parents in the independent and municipal schools mentioned educational reasons, but only one quarter of the parents in the state schools did so. About one fifth of the parents stated that they had been invited by the head. In most of the schools, representatives did not receive much encouragement from the other parents. This was the case for one third of the parents in independent schools and even less in city and state schools.

(here Table III)

The parents' representatives were also invited to tell how important it was for them to participate in the making of school policy. In all the networks, the parents' representatives found it important (mean score $\geq 4.09$ on a scale of 5; standard deviation $(\mathrm{s}) \leq 0.91)$. The same question was asked in relation to their participation in the policy making of the council. This was also considered important for them. 
These statements show a rather well motivated group of representatives. Nevertheless, the question is whether they were well prepared to the job. Research by Wolfendale (1989), and Deem, Brehony \& Heath (1995, p. 61) shows that in England many parents felt uninformed about their role. In order to answer that question for Flanders, we presented the parent governors ten statements about the rights and the responsibilities of the council for them to judge whether they were correct or not.

\section{(here Table IV)}

The low scores of the parents on these questions show that they were not yet very familiar with the rules of the council. The figure is a little higher for the state schools than for the other schools ( $\mathrm{p}=.0001)$, which might be because LSCs had already organized a higher number of meetings in state schools. The standard deviations demonstrate that some councils were doing much better than others. However, it is important to stress that the other groups did not do better on this question except for the heads. This raises the question of whether the other groups considered the parents well prepared to do the job in the council.

(here Table V)

In all networks, the competence of the parents was not very highly valued, and this appraisal was only lower for the local representatives. The lowest ratings were given by the heads, except in the independent schools where the staff was more critical. The low standard deviations indicate that this opinion is quite common in many councils. 
Does this mean that parents did not consider themselves competent to act as representatives? Not at all, but the next table shows that parents did not feel themselves to be competent in all areas of school policy.

(here Table VI)

One quarter of the parents in the independent and the municipal schools felt that they had no competence at all, while only $14 \%$ did so in the state schools. Most of the parents (six out of ten) thought that they were competent to advise on matters of general organization of the school. Another important field is educational problems: one third in the three networks considered themselves competent in educational problems. In state schools, the self-assessment of the parents was clearly higher than in the other networks.

Several things were done to inform the parents when they became members of the councils. Nevertheless, about $10 \%$ never got any information. The major source of information were brochures provided by the school (about 58\% in all networks). Interesting is also that 4 parents out of 10 themselves assembled information on how to be a good representative.

What do parents expect from their participation in the council?

\section{A. Independent schools}

Parents were not accustomed to participating in school policy making in independent schools. Since the establishment of the councils, parents were granted the right to be 
informed and consulted and to advise on matters of school policy. In spite of these new rights, rather large groups of parents wanted even more power than what was granted to the council. As far as personnel policy is concerned, depending on the issue (selection, appointment, dismissal, evaluation of the staff), $30 \%$ to $40 \%$ of the parents wanted more power, but $5 \%$ to $10 \%$ less. About $10 \%$ want more power in financial policy and $5 \%$ less, and $45 \%$ wanted to have more power in relation to policy concerning buildings and equipment. In educational matters, $25 \%$ to $35 \%$ wanted more power, $5 \%$ less. About $51 \%$ of the parents wanted to have more influence on safety policy. The organization and the operation of the school was for $50 \%$ of the parents a policy area where the council did not offer them enough power. 


\section{B. Municipal schools}

In personnel policy, $40 \%$ to $45 \%$ of the parents wanted to have more power, and $10 \%$ to $15 \%$ less. Between $15 \%$ and $25 \%$ wanted their power expanded as far as financial matters were concerned, and $10 \%$ to $15 \%$ did not; $40 \%$ wanted to have more influence in building policy and 5\% less. In educational policy, $20 \%$ to $40 \%$ wanted more power, and $57 \%$ wanted more in safety policy. Only $5 \%$ to $15 \%$ wanted less in both domains. $25 \%$ to $55 \%$ of the parents expressed the wish to have more power over the general organization of the school. Only $10 \%$ wanted less power.

\section{State schools}

As in the other school networks, parents in state schools wanted to have more power in relation to school policy than they have now. In state schools, they wanted even more than in the other networks. As far as personnel policy was concerned $40 \%$ to $60 \%$ of the parents wanted more power while only $10 \%$ wanted less. Between $20 \%$ and $30 \%$ wanted to have more influence in financial matters and $43 \%$ in building policy while only $10 \%$ wanted less. Their power in educational policy should be expanded in the opinion of $15 \%$ to $30 \%$ of the parents, and safety policy for $32 \%$ of them, while $5 \%$ to $15 \%$ did not want this. $25 \%$ to $55 \%$ wanted more power in some areas of the general organization of the school, while $10 \%$ wanted less. 


\section{Conclusion}

This description shows that large groups of parents are not satisfied with their new rights to participate in school policy. They want to have more power. Only a small group wants less power than they are granted under the new law. Nevertheless, they do not expect to expand their rights equally in all matters. This is also the case in England, where Vincent (1996) observed that parents prefer discussing organizational and extracurricular issues to curricular issues. Some fields attract more attention than others, and there are differences between the expectations of the parents in the three networks in Flanders. Nevertheless, compared with the other groups in the councils, parents feel deprived. Large groups of parents have still the feeling that they should have the right to share a larger part of the responsibility for the school policy. Wolfendale (1989) in the U.K. and Fine (1997) in the U.S.A. detected the same feelings: parents feel excluded from authority and dominated by the other governors.

What are the consequences of the council for school policy according to the parents?

After some years of experience, parents form an opinion about the influence of the council on school policy. The average scores in independent schools are very low on the domains of finance and personnel (less than 2 on 5 and $s=1.16$ and 1.17) and a little higher for educational and organization policy ${ }^{12}$ (the scores are almost 2.5). Parents certainly want the council to have more influence as is shown in Table VII $(p<.001)$. In this table the difference is between the average score of the perceived influence of the 
council and the desired influence for each policy domain. A + sign means that parents desire more influence for the council than it has: parents seem to feel deprived of what should be theirs. The figures of the municipal schools have the same pattern as those of the independent schools: very little influence on personnel and finance policy and a little higher on educational policy and organization (scores $<2.35$ ). The discrepancy between the scores for the perceived and the desired influence on school policy is, as in the independent schools, significant $(\mathrm{p}<.001)$.

(here Table VII)

In the state schools, parents as members of LSCs have real decision-making power and therefore it could be expected that they would assess the influence of the council higher than the parents' representatives in the other networks. This is also the case, but the scores are not very high, and the standard deviation is large ( $\mathrm{s}=1.18$ or more). According to the parents, the council has the most influence on finance policy (3.1 on 5) and organization (3.01 on 5), but as far as personnel policy and educational policy are concerned the average scores are 2.94 and 2.74. Since LSCs have real decision-making power, it could be anticipated that parents would have lower expectations than in the other networks. The figures confirm this hypothesis. But also in this network, it is clear that parents felt excluded $(\mathrm{p}<.001)$ from some areas of school policy. Nevertheless, these feelings were significantly stronger $(\mathrm{p} \leq .01)$ in the independent and municipal schools than in state schools for the four areas of school policy.

12 These general labels were more specified in the questionnaire in order to guarantee a common understanding of the policy categories. 
The parents were invited to answer the question: 'Does the action of the council make a difference as far as some fields of policy are concerned?' They could answer with 'a strong negative difference' (score 1), 'a negative difference' (score 2), 'no difference' (score 3), 'a positive difference' (score 4), or 'a strong positive difference' (score 5) for the different fields of school policy (Table VIII). The figures show that parents in the three networks are rather critical and do not believe that the action of the council influences school policy strongly. The least what can be said is that it does not influence school policy in the wrong direction. Nonetheless, low standard deviations suggest that in some schools parents believe that council policy does improve the school policy. This is more likely in the state schools than in the other schools as far as personnel and finance policy are concerned $(\mathrm{p}=.0001)$. Educational policy according to the parents has a more positive influence in the independent schools than in the state schools $(\mathrm{p}=.0127)$, while organizational policy, which has the strongest influence, does not differ between the three networks. Although LSCs have legally more authority than the councils in the other networks, these figures show that in practice parents only recognize this in matters of personnel and finance policy.

(here Table VIII)

In the municipal schools, the situation is less promising. The average scores tell us that parents think that the action of the council has influenced school policy in a negative direction. They are a little more positive in relation to educational policy and the general organization of the school, but here too, it is obvious that some parents are very negative about the results of the action of the council. 
At the end of the interview parents were asked whether they were satisfied with the council in general. In the independent schools, parents gave the average score of 3.35 (s $=0.99)$, in municipal schools $2.98(\mathrm{~s}=1.166)$ and in state schools $3.42(\mathrm{~s}=1.45)$ on 5 , which means that parents' representatives in the state and independent schools were significantly more satisfied than in the municipal schools $(\mathrm{p}=.007)$. In the state schools, parents show the highest satisfaction, probably because councils here have real decision-making power, but the high standard deviation indicates that this is not the case in all schools. The parents in the municipal schools have an average score, which shows that they are dissatisfied with the council in general and in a lot of schools even very dissatisfied.

Besides this general statement we tested some specific hypotheses in relation to the general satisfaction concerning the council (Table IX).

- First, we expected that when parents had more knowledge about their rights and obligations in the council they would be more dissatisfied. In none of the networks was this hypothesis confirmed.

- Second, it was expected that when parents considered it to be important to participate in the policy of the council that they would be more satisfied about the council. This hypothesis was also rejected in the three networks.

- Third, the data confirms that parents receiving suitable information to do their job as representatives are more satisfied about the council. This supports the position that parents want to be taken seriously. 
- Fourth, preceding deliberation among the parents' representatives had no influence whatsoever on the general satisfaction of the parents about the councils nor did the practice of the representatives to inform the other parents about the council.

- Fifth, only in state schools was there a positive relationship between the good functioning of the parents' association and the satisfaction about the council. The parents' associations in the other networks did not seem to have much influence on school councils.

- Sixth, in the state and municipal schools, there is a positive relationship between the influence of the council and satisfaction about the council. Whether this means that councils in independent schools have another meaning for the parents has yet to be determined.

- Seventh, when the quality of the decisions taken by the councils is high according to the parents then they are more satisfied about the council. This is the case in all three networks.

- Eighth, when parents' representatives wanted to have more influence in personnel, financial, and educational policy and in the organization of the school, figures did not show that parents were less satisfied with the council. Higher expectations towards the influence of the council in different policy areas does not seem to affect significantly the appraisal of the council by the parents, except in the state schools where parents, expecting more influence on personnel policy, value the council more highly. This relationship is unlikely and needs more research. 
- Ninth, the more parents believe that the action of the council influences positively the policy in relation to personnel, finance, education and organization, the more they value the council. This relationship was found in the three networks.

- Tenth, we had expected that the parents' representatives would value the council more when they felt themselves more competent in the different domains of the policy, i.e. policy concerning personnel, finance, education, or organization. In none of the networks did the figures support this hypothesis.

(here Table IX)

\section{Conclusions}

The establishment of councils in schools has created new opportunities for democratic participation in decision-making in school policy. Depending on the networks, the level of involvement of the parents is weak or strong. In state schools, parents participate in a council with real decision-making power, whereas in the two other networks the council only has the right to be informed or to advise. Consequently, it could be expected that the members in the councils would act differently, and this is often supported by the figures.

But before presenting more specific conclusions, it should be stressed that it would not be correct to reduce the picture of the action of the councils to the average scores of the assessment of the councils by the parents. The standard deviations show that the action of the councils may vary strongly between councils in the opinions of the parents. 
Councils differ, which we had already discovered in an earlier study of 12 schools using in-depth interviewing (Verhoeven \& Gheysen, 1993). Moreover, the picture presented in this article is only the picture painted by the parents, and this is different from the picture presented by heads, teachers, etc. (Verhoeven, Jegers \& Van Heddegem, 1997).

On average, the parents' representatives were not much satisfied with the council in general, though it has to be stressed that parents in councils with real decision-making power (state schools) were more satisfied than the others. These parents also had a slightly stronger average feeling that councils make a difference in policy. These feelings most probably contribute to the fact that parents' representatives in these schools, although they do not feel themselves very powerful and want much more power in particular areas of policy, felt themselves less deprived than did parents in other schools. This statement, together with the higher deprivation scores of parents in the other networks, show the direction in which the position of parents in councils should develop.

Although Parliament wanted to give the parents democratic representation in the councils, the operation did not succeed as far as the representation of the different socioeconomic groups are concerned. The parents, just like in other democratic councils and countries, are represented by middle-class parents (Munn, 1992; Fine, 1997). Since there is no good system for giving feed back on the decisions of the councils to the parents, this might have the opposite effect: only the groups that were already well informed will receive more information. 
On the other hand, parents in councils are well motivated to do their duty in the councils, although this research has also shown that they do not know very much about the regulations governing the council. Moreover, they have often to face a rather low appreciation of their competence by the other groups on the council. This does not strengthen the position of the parents. In this context, it should be remembered that parents with a better knowledge than other parents about their rights and obligations did not appreciate the council more. This might indicate that parents do not care about the rules, and that they believe that the chairperson will take care of all the technical problems in the council.

Although the policy areas are very diversified, parents are more interested in some fields than in others (Chapman, 1990). The general organization of the school and the educational policy attract their main interest. Only in the state schools was a rather large group also interested in problems of personnel and finance. Most of the parents wanted to stick to policy areas they were familiar with, but there was still a rather large group who did not feel themselves competent at all to act in the council.

The legal structure of the councils shows that the establishment of these councils is a good step in the direction of wider participation in school policy by the parents, but it still suffers from many deficiencies. In a fourth of the councils no elections were organized. Parents should be prepared better to do their job as council members, and the structure of the election and the council should be adapted to improve democratic representation. Councils need to develop a new culture of cooperation in order to give the parents a real say in school policy. 


\section{References}

Chapman, J. ed. (1990) School-based Decision-Making \& Management, London/New York: The Falmer Press.

Deem, R. (1994) Free marketeers or good citizens? Educational policy and lay participation in the administration of schools, British Journal of Educational Studies, 1: 23-37.

Deem, R. (1996) The school, the parent, the banker and the local politician: What can we learn from the English experience of involving lay people in the site-based management of schools?, pp. 55-70 in C.J. Pole, R. Chawla-Duggan (Eds.) Reshaping Education in the 1990s: Perspectives on Secondary Schooling. London/New York: The Falmer Press.

Deem, R. \& Brehony, K. (1992) Can consumers and education professionals work together in winning schools?, pp. 75-82 in F. Smit, W. Van Esch, H.J. Walberg (Eds.) Parental Involvement in Education. Nijmegen: ITS.

Deem, R., Brehony, K. \& Heath, S. (1995) Active citizenship and the governing of schools. Buckingham/Philadelphia: Open University Press.

Devos, G., Vandenberghe, P. \& Verhoeven, J.C. (1989) Schoolbeleid: Mogelijkheden en Grenzen. Een Empirisch Onderzoek. Leuven/Amersfoort: Acco.

Fine, M. (1997) (Ap)parent Involvement: Reflections on Parents, Power, and Urban Public Schools, pp. 460475 in A.H. Halsey, H. Lauder, P. Brown \& A.S. Wells (Eds.) Education: Culture, Economy, Society, Oxford/New York: Oxford University Press.

Golby, M. (1992) Parents as school governors, pp. 65-86 in P. Munn (Ed.), Parents and Schools: Customers, Managers or Parents? Routledge: London.

ILEA (1987) Improving home-school relations in London's schools, pp. 129-141 in J. Bastiani (Ed.) Parents and Teachers II: From Policy to Practice. Berkshire: NFER-Nelson.

Johnson, D. \& Ransom, J. (1987) Family and school - the relationship re-assessed, pp. 59-71 in J. Bastiani (Ed.) Parents and Teachers II: From Policy to Practice, Berkshire: NFER-Nelson.

Munn, P. (1992) Parents as school board members: school managers and friends, pp. 87-100 in P. Munn (Ed.), Parents and Schools: Customers, Managers or Parents?. London: Routledge.

Sallis, J. (1988) Schools, Parents and Governors: A New Approach to Accountability, London: Routledge.

Thody, A. (1989) Who are the governors?, Educational Management and Administration, 17: 139-146.

Vanderhoeven, J. (1991-1992) Medezeggenschap: een duik in de lokale autonomie, Tijdschrift voor Onderwijsrecht en Onderwijsbeleid, 3: 157-172.

Verhoeven, J.C., Fosty, G. \& Gaignage, R. (1992) Federalization, decentralization, devolution and deregulation, pp. 381-403 in Education in Belgium: The Diverging Paths. Brussel-Bruxelles-Eupen: Ministerie van de Vlaamse Gemeenschap, Departement Onderwijs-Ministère de l'Education, de la Recherche et de la Formation-Verwaltung der Deutschsprachigen Gemeinschaft,Abteilung Unterricht.

Verhoeven, J.C. \& Gheysen, A. (1993) Scholen en nieuwe voorschriften. Een evaluatie door directies, leerkrachten en ouders. Leuven: Sociologisch Onderzoeksinstituut.

Verhoeven, J.C. \& Gheysen, A. (1993) The Effectiveness of Schooling and Educational Resource Management in Belgium (Flanders). OECD report. Leuven: Departement Sociologie/ Sociologisch Onderzoeksinstituut.

Verhoeven, J.C., Jegers, M. \& Van Heddegem, I. (1997) Participatieraden en lokale schoolraden in Vlaanderen. De eerste jaren. Leuven: Garant.

Vincent, C. (1996a) Parent empowerment? Collective action and inaction in education, Oxford Review of Education, 4: 465-482.

Vincent, C. (1996b) Parents and Teachers: Power and Participation. London: Falmer Press. 
Wolfendale, S. (1989) Parental involvement and power-sharing in Spspecial needs, pp. 106-119 in S. Wolfendale (Ed.) Parental Involvement: Developing Networks Between School, Home and Community. London: Cassell. 
Table I. Parents' representatives in the three school networks by sex (\%)

\begin{tabular}{|c|c|c|c|}
\hline School network & Men & Women & Total \\
\hline State schools & 69 & 31 & 24 \\
\hline Municipal schools & 61 & 39 & 23 \\
\hline Independent schools & 56 & 44 & 53 \\
\hline Total & 61 & 39 & $100(\mathrm{~N}=694)$ \\
\hline
\end{tabular}


Table II. Parents' representatives in the three networks by socio-economic position (\%)

\begin{tabular}{|c|c|c|c|c|c|c|c|}
\hline $\begin{array}{l}\text { School } \\
\text { network }\end{array}$ & $\begin{array}{l}\text { House- } \\
\text { wives }\end{array}$ & $\begin{array}{l}\text { Entre- } \\
\text { preneurs }\end{array}$ & $\begin{array}{l}\text { Clerical } \\
\text { workers }\end{array}$ & Workers & Retired & $\begin{array}{l}\text { Un- } \\
\text { employed }\end{array}$ & Total \\
\hline State schools & 6 & 16 & 59 & 10 & 8 & 2 & 24 \\
\hline $\begin{array}{l}\text { Municipal } \\
\text { schools }\end{array}$ & 10 & 10 & 70 & 7 & 1 & 3 & 23 \\
\hline $\begin{array}{l}\text { Independent } \\
\text { schools }\end{array}$ & 13 & 12 & 68 & 5 & $\backslash$ & 2 & 53 \\
\hline Total & 11 & 12 & 66 & 7 & 2 & 2 & $\begin{array}{l}100 \\
(\mathrm{~N}=692)\end{array}$ \\
\hline
\end{tabular}


Table III. Motives of parents' representatives to run for membership of the council by school networks (\%) ${ }^{13}$

\begin{tabular}{|c|c|c|c|}
\hline Motives & Independent schools & Municipal schools & State schools \\
\hline Invited by the head & 19 & 20 & 21 \\
\hline Ideological reasons & 18 & 27 & 42 \\
\hline Political reasons & 1 & 1 & 6 \\
\hline Educational reasons & 32 & 38 & 24 \\
\hline Commitment to school & 79 & 82 & 71 \\
\hline Commitment to network & 15 & 13 & 56 \\
\hline Invited by other parents & 36 & 21 & 12 \\
\hline
\end{tabular}

13 Percentages of columns do not add to 100 because more than one answer could be given. 
Table IV. Average number of correct answers of the parents' representatives on 10 statements concerning the rights and responsibilities of the council in the school networks (maximum score $=10$ )

\begin{tabular}{|l|l|l|l||}
\hline & Independent schools & Municipal schools & State schools \\
\hline Average score & 4.586 & 4.271 & 5.762 \\
\hline Standard deviation & 1.904 & 2.198 & 1.670 \\
\hline
\end{tabular}


Table V. Average scores of the assessment of the competence of the parents' representatives by the other groups in the three networks (maximum score=5)

\begin{tabular}{|c|c|c|c|c|}
\hline & $\begin{array}{l}\text { Organizing } \\
\text { authorities }\end{array}$ & Local representatives & Staff & Headmaster \\
\hline Independent schools & $\begin{array}{l}3.737 \\
(s=0.808)\end{array}$ & $\begin{array}{l}3.923 \\
(s=0.770)\end{array}$ & $\begin{array}{l}3.456 \\
(\mathrm{~s}=0.839)\end{array}$ & $\begin{array}{l}3.527 \\
(\mathrm{~s}=0.522)\end{array}$ \\
\hline Municipal schools & $\begin{array}{l}3.615 \\
(s=0.903)\end{array}$ & $\begin{array}{l}3.707 \\
(s=0.871)\end{array}$ & $\begin{array}{l}3.460 \\
(s=0.800)\end{array}$ & $\begin{array}{l}3.498 \\
(s=0.467)\end{array}$ \\
\hline State schools & 14 & $\begin{array}{l}3.163 \\
(\mathrm{~s}=0.823)\end{array}$ & $\begin{array}{l}3.524 \\
(\mathrm{~s}=1.154)\end{array}$ & $\begin{array}{l}2.915 \\
(s=0.495)\end{array}$ \\
\hline
\end{tabular}

14 Since the LSC in state schools is combined with the general council of the ARGO, the organizing authority, this item is not applicable. 
Table VI. Opinion of the parents' representatives about domains of competence in school policy in the school networks $(\%)^{15}$

\begin{tabular}{||l|l|l|l||}
\hline \hline Domains of competence & Independent schools & Municipal schools & State schools \\
\hline Personnel & 12 & 9 & 41 \\
\hline Finance & 25 & 17 & 35 \\
\hline Educational & 36 & 30 & 28 \\
\hline Organization & 59 & 63 & 66 \\
\hline None & 25 & 23 & 14 \\
\hline \hline
\end{tabular}

15 Percentages of columns do not add to 100 because more than one answer could be given. 
Table VII. Difference between average (parental) scores for perceived and desired influence of councils on school policy broken down by school network

\begin{tabular}{||l|c|c|c||}
\hline \hline \multicolumn{1}{|c||}{ Policy domain } & Independent schools & Municipal schools & State schools \\
\hline Personnel & +1.3 & +1.6 & +0.7 \\
\hline Finance & +1.3 & +1.3 & +0.8 \\
\hline Educational & +1.3 & +1.4 & +0.8 \\
\hline Organization & +1.2 & +1.4 & +0.9 \\
\hline
\end{tabular}


Table VIII. Average parental assessment about the difference produced by the council on different areas of school policy (maximum score=5)

\begin{tabular}{|c|c|c|c|}
\hline Policy Areas & Independent schools & Municipal schools & State schools \\
\hline Personnel & $\begin{array}{l}3.101 \\
(s=0.604)\end{array}$ & $\begin{array}{l}2.960 \\
(s=0.704)\end{array}$ & $\begin{array}{l}3.466 \\
(s=0.894)\end{array}$ \\
\hline Finance & $\begin{array}{l}3.118 \\
(s=0.603)\end{array}$ & $\begin{array}{l}2.984 \\
(s=0.701)\end{array}$ & $\begin{array}{l}3.403 \\
(s=0.815)\end{array}$ \\
\hline Education & $\begin{array}{l}3.345 \\
(s=0.594)\end{array}$ & $\begin{array}{l}3.239 \\
(\mathrm{~s}=0.685)\end{array}$ & $\begin{array}{l}3.224 \\
(s=0.789)\end{array}$ \\
\hline Organization & $\begin{array}{l}3.396 \\
(s=0.645)\end{array}$ & $\begin{array}{l}3.327 \\
(s=0.771)\end{array}$ & $\begin{array}{l}3.497 \\
(s=0.847)\end{array}$ \\
\hline
\end{tabular}


Table IX. Relation between some variables and satisfaction with the council in the school networks (analysis of variance: $\mathrm{R}^{2}$ )

\begin{tabular}{|c|c|c|c|}
\hline Independent variables & State schools & $\begin{array}{l}\text { Municipal } \\
\text { schools }\end{array}$ & $\begin{array}{l}\text { Independent } \\
\text { schools }\end{array}$ \\
\hline Knowledge & - & - & - \\
\hline Importance to participate & - & - & - \\
\hline Information & $.17^{* *}$ & $.21 * *$ & $.12^{* *}$ \\
\hline Preceding deliberation & - & - & - \\
\hline Quality of functioning of parents' associations & $.08^{*}$ & - & - \\
\hline Influence of the council & $.14^{* *}$ & $.12^{* *}$ & - \\
\hline Quality of the decisions & $.30 * *$ & $.26^{* *}$ & $.18^{* *}$ \\
\hline Desired influence on personnel policy & $.07 * *$ & - & - \\
\hline Desired influence on finance policy & - & - & - \\
\hline Desired influence on educational policy & - & - & - \\
\hline Desired influence on organizational policy & - & - & - \\
\hline Difference the council makes on personnel policy & $.17^{* *}$ & $.06^{*}$ & $.15^{* *}$ \\
\hline Difference the council makes on finance policy & $.12^{* *}$ & $.11 * *$ & $.15^{* *}$ \\
\hline Difference the council makes on educational policy & $.10^{* *}$ & $.12^{* *}$ & $.23^{* *}$ \\
\hline Difference the council makes on organ. policy & $.15^{* *}$ & $.11^{* *}$ & $.17^{* *}$ \\
\hline Competence in personnel policy & - & - & - \\
\hline Competence in finance policy & - & - & \\
\hline Competence in educational policy & - & - & - \\
\hline Competence in organizational policy & - & - & - \\
\hline
\end{tabular}

$* \mathrm{p} \leq .005 ; * * \mathrm{p} \leq .0005 ;-=$ n.s. 